\title{
The basic trends of honors education in universities worldwide
}

Russian universities start to follow the tradition of creating special educating areas for talented students with high academic achievements, i.e. honors students. However few studies in Russia have examined the phenomenon of honors colleges, as well as the principles of honors education's theory and the turning points of its history. The aims of the study are to analyze the reasons institutions of higher education worldwide invest significant financial and human resources into the talent development in various honors programs and to assess the perspectives of applying international standards to the development of the elite undergraduate education in Russian universities. The current study uses the methods of qualitative research including phenomenological method to examine the honors college phenomenon, the content analysis of fundamental texts produced in the context of honors education theory and the case study method to describe several outstanding honors programs in American, European and Russian universities. The author focuses her attention on cases of the honors programs in Illinois State University, Windesheim University of Applied Sciences, the University of Tyumen and Siberian Federal University. The case study of SibFU Honors College suggests the growth of popularity and trends for future development of honors education in the Russian Federation.

Key words: honors education, elite education, higher education, talented students, high ability, university, 21st century soft skills

\section{For Reference:}

Tarasova, M. V. (2019). The basic trends of honors education in universities worldwide. Perspektivy nauki i obrazovania - Perspectives of Science and Education, 38 (2), 38-46. doi: 10.32744/ pse.2019.2.3 


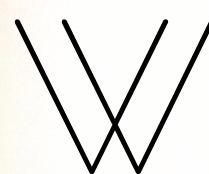

hen Siberian Federal University hosted the inaugural International Honors College Conference. Krasnoyarsk 2018 on November 30 - December 1, 2018, prominent scholars and practitioners of honors education worldwide attended it to discuss the future of higher education in the context of supporting the development of high ability students that have outstanding academic achievements. It is evident that honors programs for gifted and talented students can be the trend of elite undergraduate higher education in Russian universities in the nearest decades. Honors phenomenon turns into a global movement in the USA, Asia, Benelux, Nordic and German-speaking countries in Europe. Russian universities have started the process of becoming members of this global honors community with SibFU Honors College of Siberian Federal University and the Centre of Elite Education in South Ural State University joining the National Collegiate Honors Council $(\mathrm{NCHC})$ - an international association with more than nine hundred members from nine different countries. Talent development becomes the priority in universities today because top-managers of higher education realize that high ability students are the individuals that grow into professional leaders and innovative scholars able to shape the future of society and science. Special educational environment for this kind of students benefits the universities as strategic centers of transforming human potential into human capital. Honors programs in universities are formed according to a certain ideal pattern of an individual with skills, competences and strengths essential for a successful career in any professional field in the twenty-first century. For managers of Russian higher education institutions that join the global honors education movement it is important to get insight into the basic principles of the honors pedagogies and to understand the values that honors educators share worldwide. The aim of the study is to contribute to achieving these goals by analyzing the theoretical texts and best practices of honors education in foreign countries and in Russia as well.

Methods

The phenomenological method is applied to examining the honors college phenomenon as the main study object. The content analysis of fundamental texts produced in the context of honors education theory, e.g. the research made by Marca Wolfensberger, Peter Sederberg etc., allows getting insight into the various aspects of the phenomenon of the honors college and the honors program. Since the honors education positions itself as an dynamic area of constant pedagogic experiments, the case study represents the most effective method in exploring certain honors programs in American, European and Russian universities, scanning their convergences as well as inevitable differences and peculiarities.

Results

Peter Sederberg, the author of the study 'Honors College Phenomenon' [26], in his investigation of the entitled phenomenon begins with understanding the origins of the first honors programs for talented students organized in the universities in the middle of the twentieth century. Sederberg comes to conclusion that when number of universities fail to 
offer fully adequate opportunities for well-prepared, talented, and ambitious undergraduates almost everyone looses: talented students, the institutions and their faculties, the supporters of public higher education. The mission of the honors program created as a solution to this problem is to offer the best students a richer educational experience and to enhance the institution's reputation for academic excellence.

According to Sederberg, the aims of programs of honors education are to attract and bring together able and ambitious students who commit themselves to the project of becoming educated members of a democratic society; to help them understand they are pursuing education for life, citizenship and career; to create a set of curricular and cocurricular opportunities that can provide such an education; to organize the resources of the university for those students to benefit. Making a university more competitive in attracting and retaining high-performing students neither reflects only a market-driven concern, nor it is a form of vanity. Sederberg stresses that presence and cultivation of committed students enhances the educational mission of every university.

The history of honors education worldwide demonstrates that mission of honors colleges is to promote or advocate a particular educational project, reform [5; 8; 9]. Honors colleges frequently advocate liberal learning but are not necessarily limited to the studies of the humanities. For structuring of the honors college one cannot use disciplinary colleges as analogs; honors colleges tend to involve its students into interdisciplinary research and teamwork. Honors college is organized as a new form of educational activity within the university $[22 ; 24 ; 25]$. Laurie Kramer, the director of the university Honors Program at the Northeastern University, defines honors colleges as universities' 'innovation playgrounds'. M. Wolfernsberger, A. Pilot, P.J. Van Eijl [35] name honors programs laboratories for educational innovation'. These definitions call for realizing the creative capacities of honors colleges where the experiments in teaching and learning lead to changing the traditional methods of higher education and transforming the attitude of learners and educators to aims and results of the educating process. Working out a special educational program for able and ambitious students demands teaching on the higher level, providing support for each individual's full actualization of her potential.

Honors education is a specially designed education for gifted and talented students who want to do more than the regular program offers [33]. The enriched learning experience provided by these programs is focused on broadening and creating new knowledge with special attention for more generic competences. The honors programs meet the needs of talented students 'to go beyond the beaten tracks' [35] and offer possibilities to students to distinguish themselves [2].

The research carried out by the scholars in Netherlands universities $[1 ; 11 ; 12 ; 35]$ suggest that honors students are individuals with certain characteristics necessarily taken into consideration when planning the honors programs formats and content. Honors students are eager, wanting to investigate, experience things and to experiment. They are intrinsically motivated, ambitious and score high on autonomy. They appreciate freedom to work on their development. More often than average they are open to new experiences, participate in activities outside of their studies because they find them meaningful [3]. Honors students are generally enthusiastic, result-oriented, self-directing and conscientious [5].

As T. Kingma, K. Dommerholt and L. Rijsdijk conclude in their research [11], numerous studies show that honors students value the following points in honors programs: studentteacher interaction, community formation, practice-orientedness and authenticity, room for initiative, small scale of the organization, mutual choice for participation, an interest in 
other areas than their study program. When the scholars apply these results to organizing specific honors education environment in universities they realize that 'in order to be able to make honors programs successful for students, it is important to keep feeding their intrinsic motivation' [11, p.19] because motivated students have a strong need for a teacher who supports them in their need for autonomy [18].

Research done by Marca Wolfesnberger [33; 34], the president of the European Honors Council, shows three pillars of honors pedagogy that are characteristic for teaching in honors programs. These pillars are: creating community, stimulating academic competencies and offering freedom. The scholars [11] have found the strong resemblance of these pillars to the principles of the self-determination theory [23]. According to self-determination theory, intrinsic motivation of students in general is fed when three psychological basic needs are met, which are autonomy, competence (mastery) and connectedness. These principles were employed to the practice of organizing the honors learning environment of Windesheim University of Applied Sciences [11], where a teacher, apart from connectedness, can also offer a good balance between autonomy and structure. The Windesheim Honors learning environment consists of eight characteristics which support learning by honors students through multidisciplinary connections, creative productivity, authentic assignments, personal learning journey, social responsibility, concept of giftedness, learning communities and personal leadership. Pedagogy of giftedness is the area of studies that constantly supplies honors educators with new resources worldwide [16; 17; 21; 28].

Organizers of the Windesheim honors learning environment define talents as strengths which make individuals stand out, compared to others. A strength-based approach leads to stronger teams. In honors education, teachers, motivated and gifted students and professionals work together. Honors faculty and students make teams where each member plays an equally important role of actors, subjects of educating forces.

In her presentations at Honors National Collegiate Honors Council annual conference 2018 and at the Honors College Conference. Krasnoyarsk 2018 Laurie Kramer claimed that honors programs have the capacity to transgress boundaries to have broader impact on learning and student development, within and beyond classroom walls. Dr. Kramer noted that honors programs and colleges have long been prized by their campuses for their ability to attract, yield, and retain high-achieving students. They have done this by offering highachieving students exceptionally high quality courses, personal access to faculty, advising, global experiences, opportunities for research and creative endeavors, and in some cases unique residential experiences and scholarships. The focus has been on enabling highachieving students to flourish, intellectually, socially, globally, and professionally, all the while meeting their distinct learning needs as curious, engaged, and prolific learners.

Still Laurie Kramer believes that honors programs have the capacity to do much more for their campuses, even if not every member of the university community is a formal member. Dr. Kramer, who is in charge of honors programs at Northeastern university in Boston and who turned honors programs into the university's Innovation Playground, declares that the University Honors Program at Northeastern has intentionally sought opportunities to work with faculty and campus professionals to design and test new opportunities for learning and to provide a site for the ideating, prototyping, testing and revision of new initiatives.

Becoming recognized as a site for innovation and experimentation can provide a mechanism for building support across the campus. The initiatives developed through Honors are later brought to other departments. Honors may be a program that caters only to the "elite" to one that can benefit all students on the campus. 
The goal of the honors program at the Northeastern University is for the entire campus to view Honors as the place to experiment with new models. Honors is not simply representing a "niche" program for a select few, but is an essential player in the discussion of how to best design and implement educational innovations that will move our university forward.

The Honors Program at the Illinois State University is based on the learning framework called ' $6 \times 6$ ' designed in accordance with learning outcomes intended to be developed by students upon completion of the program. The organizers of the honors program at the Illinois State University called the learning outcomes the dimensions of honors learning. The dimensions are woven throughout the opportunities - honors learning experiences provided for students.

When considering learning outcomes, the organizers of the Illinois State University honors program examined the types of skills they intended their students to develop upon graduation from the university and the honors program. The study resulted in six dimensions of honors learning, essential for students to be successful in their careers and as global citizens. The dimensions of honors learning are critical thinking [15], interdisciplinary learning, information fluency, creative productivity, leadership development, intercultural competence. Students participate in the honors program by completing honors learning experiences. These experiences help students develop the dimensions of honors learning and they include honors seminars, honors contracts, honors explorations, honors sections, honors research and honors travel.

\section{Discussion}

In Russian higher education the reasons for creating special learning environment for gifted and talented students are determined by the necessity to adapt future graduates to the rapidly changing world. In the time of global competition, it is impossible to limit changes to improving existing institutions in response only to internal requests. Increasing competitiveness is determined by the ability to create new institutions to solve new problems and to meet external, national and global needs. There are four dimensions of global competition: the quantity and quality of human capital; degree of social sustainability, technological innovation, international influence. The key factor in global competition today is the quality and quantity of human capital. One of the main tasks of modern education is to manage the transformation of human potential into human capital; contribute to increasing the quantity and improving the quality of human capital.

In Russian Federation various forms of honors education emerged in the process of the development of Russian Academic Excellence project 5top100. Among the members involved in the project are the University of Tyumen, South Ural State University, Siberian Federal University, where different formats of honors programs attract the best students of these universities.

The organizer of the School of Advanced Studies (SAS) at the University of Tyumen Andrey Scherbenok claims that their strategic goal is to provide a unique, high-quality education for the best prepared, most talented, and most highly motivated students from Russia and abroad and to contribute to the global debate on the most important problems in the area of social sciences and humanities, life sciences and IT. The School of Advanced Studies defines itself as an elite honors college that features outstanding students in dialogue across fields of knowledge. The educational program of SAS offers students the 
opportunity to undertake interdisciplinary study across the social sciences and humanities, extending to their intersection with information technology and the biological sciences, and offering wide latitude and personal choice regarding the individual's educational path. The baccalaureate program is bilingual (Russian and English). The classroom format is predominantly interactive small-group sessions, with students able to choose their major after the second year. An interdisciplinary required course of study is modeled on the core curricula of leading universities, while one-third of the course load consists of electives selected by students from dozens of unique courses developed by the SAS faculty.

In determining the quality of human capital, Russia faces the challenges of the weak development of the 21st century skills [4]. 21st century skills are universal academic skills as effective communication, cooperation (ability for collective thinking, teamwork), critical thinking [27], motivation, initiative, interest in their work, and creativity. Scholars [30] note that honors programs are frequently regarded as inspiring for redesigning curricular in higher education that incorporate 21st century skills. '21st century skills' are concepts that describe effective functioning in the individual's professional activities of the nearest decades of the century. They are generic skills with related knowledge, insight and attitudes. The skills are considered necessary in 'a society that is rapidly changing with computers and technology replacing a lot of human labor, creating new opportunities, digital intelligence (big data), becoming more global and bringing new ethical dilemmas' [30, p.41]. International researchers (supported by Microsoft, Cisco and Intel) have studied these skills and reported on these in the KSAVE-model (Knowledge, Skills, Attitudes, Values and Ethics) [7]. In the Netherlands Utrecht-based research group on 21st century skills of the Freudenthal Institute made a model for secondary and tertiary education with the following categories: creativity, problem-solving, collaboration and communication, ICT literacy and self-regulation. Some universities have already incorporated these skills in their policy plans. For instance, Windesheim University of Applied Sciences in their Educational Concept declares the following skills to be the outcomes of studies for their honors students: critical thinking and analytical skills, demonstrating leadership and taking responsibility, being innovative, inquisitive, creative and flexible, initiative-taking and having entrepreneurial spirit, co-operation, interpersonal skills and problem-solving mindset.

In Russia SibFU Honors College joins the number of honors programs devoted to the development the 21st century skills in their honors students. Honors College of Siberian Federal University (Krasnoyarsk) is one of the pioneers in the honors education movement in Russia. The mission of SibFU Honors College is to contribute to the development of the creative personalities of students who are ready for an active realization of their own potential. SibFU Honors College provides students with a new, alternative learning experience. SibFU HC was created for the second and the third year undergraduates of all institutes and schools of Siberian Federal University - talented students with the high level of academic achievements. They are gifted, ambitious individuals, self-motivated and open for new knowledge.

The program of SibFU Honors College program is specifically designed to achieve the goal of developing the competencies and skills of the 21st century: communication skills, cooperation, leadership, critical thinking, creativity, ability to find positive solutions in conflicts, visual thinking, capacity for self-learning and self-improvement. Leadership skills are among the most valued in individuals as personal agents [10].

The courses comprising the program of SibFU Honors College are the directions of learning activity which allow students developing 21st century skills in order to be successful 
in future career and life. The courses include Effective communication in negotiating and debates; Public speaking; Visual thinking; Theory of knowledge; Individual psychology in organizational settings; Academic networking in the international community; Self-learning techniques; Decision making and practice of leadership; Positive solutions in conflicts; Critical thinking; Creative thinking; Global issues; Project management.

The faculty working with students of the SibFU Honors College have the characteristics found essential in honors pedagogies worldwide: intention of self-improvement, commitment to educational innovations, potential for pedagogical creativity, for producing new learning techniques, experimental academic programs, innovative assignments; ability to take differential teaching responsibilities, to apply individual approach to working with students, capacity for teaching well-prepared, able, gifted, ambitious individuals; aptitude for providing support for each individual's full actualization of her potential.

The methodology in the basis of the educational program of SibFU HC is structured according to the principles of the developmental learning, concept of enthusiastic education, principles of liberal education and the theory of educating games. The classes at SibFU Honors College are conducted in the format of organizational activity games, business games, learning games, discussions, debates, project-making and other forms of edutainment. A form and content of the educating game makes every class an unforgettable event for both students and teachers.

The organizational activity game is a special form and method for the organization of collective thinking and thinking activity. In education the purpose of the game is the development and study of new forms of instruction and learning in universities. Series of organizational activity games structure the learning process at the SibFU Honors College as landmarks of its development. The purpose of the introductory inaugural macro-game is to involve students and faculty into the process of collective learning in the new institution of the Honors College.

Various kinds of educating games in SibFU Honors College allow achieving its goal, i.e. to develop 21st century skills in students and to create a new educational institution aimed at improving the quality of human capital through supporting research and educational activities of talented students of the Siberian Federal University.

Conclusion

Honors College is approached by scholars and practitioners as the creative laboratory of the university. The educational initiatives that have arisen here can contribute to the development of the university as a whole. Each honors college and each honors program is different. Still they are united by the pedagogic principle of developing initiative in both faculty and students and are mutually committed to nurturing the enthusiastic spirit of personal agency in students as managers of their constructive relationship with society and the world.

Higher education, unfortunately, is mainly focused on a student with average abilities. The development of gifted students is a particularly difficult task, the solution of which still needs priority status. After all, it is talented students with high educational inquiries who turn out to be those unique units capable of making a scientific and technical breakthrough or discovery that changes the world. Today, when the need to harmonize the development of science and higher education has become obvious, the value of an elite group of a gifted 
minority should increase immeasurably. It is undoubtedly the future of higher education. And the development of Honors College programs contributes to the achievement of this kind future for Russian university graduates.

\section{REFERENCES}

1. Achtenberg, C. What is an Honors Student? Journal of the National Collegiate Honors Council, 2005, 6 (1), pp. 75-83.

2. Adam, K., Zinn, D., Kemp, H., Pieterse, C. Humanising research through research: The inclusion of student voice in curriculum renewal. Education as Change, 2014, 18 (SUPPL.1), pp. 63-76.

3. Bai, H., Eppert, C., Scott, C., Tait, S., Nguyen, T. Towards Intercultural Philosophy of Education. Studies in Philosophy and Education, 2015, 34 (6), pp. 635-649.

4. Binkley, M., Erstad, O., Herman, J., Raizen, S., Ripley, M., Rumble, M. Defining 21st century skills. Melbourne: University of Melbourne. 2010.

5. Bowman, N.A., Culver, K. When Do Honors Programs Make the Grade? Conditional Effects on College Satisfaction, Achievement, Retention, and Graduation. Research in Higher Education, 2018, 59 (3), pp. 249-272.

6. Charyton, C., Snelbecker, G.E., Rahman, M.A., Elliott, J.O. College students' creative attributes as a predictor of cognitive risk tolerance. Psychology of Aesthetics, Creativity, and the Arts, 2013, 7 (4), pp. 350-357.

7. EUROlocal. Inventory of 21st century skills and competencies in a learning region, 2017. Available at: http:// eurolocal.info/resource/inventory-21st-century-skills-and-competencies-learning-region (accessed 12 January 2019).

8. Fishman, T.T. Academic integrity as an educational concept, concern, and movement in US institutions of higher learning. Handbook of Academic Integrity, 2016, pp. 2-21 (book chapter).

9. Griffoen, D. M. E., Doppenberg, J.J., Oostdam, R.J. Are more able students in higher education less easy to satisfy? Higher Education, 2018, 75 (5), pp. 891-907.

10. Ho, S.S., Wong, B.B.M., Tham, M., Brooks, R.H. Science undergraduates are motivated to undertake leadership education to enhance employability and impact. International Journal of Innovation in Science and Mathematics Education, 2016, 24 (3), pp. 71-83.

11. Kingma, T., Dommerholt, K., Rijsdijk, L. The honours learning environment of Windesheim University of Applied Sciences. Journal of the European Honors Council, 2017, 1 (2), pp. 17-30.

12. Kool, A., Mainhard, T., Jaarsma, D., van Beukelen, P., Brekelmans, M. Effects of honours programme participation in higher education: a propensity score matching approach. Higher Education Research and Development, 2017, $36(6)$, pp. 1222-1236.

13. Lim, F., Nelson, N., Stimpfel, A.W., Navarra, A.-M., Slater, L.Z. Honors programs: Current perspectives for implementation. Nurse Educator, 2016, 41 (2), pp. 98-102.

14. Mc Taggart, B., Cavaliero, T. A change will do you good. Innovations in Education and Teaching International, 2016, 53 (5), pp. 555-565.

15. McLaughlin, A.C., McGill, A.E. Explicitly Teaching Critical Thinking Skills in a History Course. Science and Education, 2017, 26 (1-2), pp. 93-105.

16. McLaughlin, J. Working With Gifted College and University Students: Journals, Organizations, and Scholarships. Reference Librarian, 2015, 56 (1), pp.42-51.

17. Mullet, D. R., Kettler, T., Sabatini, A.M. Gifted Students' Conceptions of Their High School STEM Education. Journal for the Education of the Gifted, 2018, 41 (1), pp. 60-92.

18. Nunez, J. L., Fernandez, C., Leon, J., Grijavo, F. The relationship between teacher's autonomy support and students' autonomy and vitality. Teachers and Teaching, 2014, 21 (2), pp. 191-202.

19. Perera, S., Babatunde, S.O., Zhou, L., Pearson, J., Ekundayo, D. Competency mapping framework for regulating professionally oriented degree programmes in higher education. Studies in Higher Education, 2017, 42 (12), pp. 2316-2342.

20. Pigden, L., Moore, A.G. Employability outcomes for university joint honours graduates. Higher Education, Skills and Work-based Learning, 2018, 8 (2), pp. 195-210.

21. Renzulli, J.S. The three-ring conception of giftedness: A developmental Model for Promoting Creative Productivity. In R.J. Sternberg \& J.E. Davidson (Eds.). Conceptions of Giftedness, 2005, pp. 246-279. New York: Cambridge University Press.

22. Richards, D., Saddiqui, S., White, F., Mc.Guigan, N., Homewood, J. A theory of change for student-led academic integrity. Quality in Higher Education, 2016, 22 (3), pp. 242-259.

23. Ryan, R.M. Deci, E.L. Self-determination theory: Basic psychological needs in motivation, social development, and wellness. New York, NY, US: Guilford Press. 2017.

24. Scager, K., Akkerman, S. F., Pilot, A., Wubbels, T. Challenging high-ability students. Studies in Higher Education, 2014, 39 (4), pp. 659-679.

25. Scager, K., Akkerman, S. F., Pilot, A., Wubbels, T. How to persuade honors students to go the extra mile: creating a challenging learning environment. High Ability Studies, 2013, 24 (2), pp. 115-134. 
26. Sederberg, P. (2015) The Honors College Phenomenon. Available at: http://digitalcommons.unl.edu/cgi/ viewcontent.cgi?article=1003\&context=nchcmono (accessed 12 January 2019).

27. Sheffield, C. B. Promoting Critical Thinking in Higher Education: My Experiences as the Inaugural Eugene $\mathrm{H}$. Fram Chair in Applied Critical Thinking at Rochester Institute of Technology. Topoi, 2018, 37 (1), pp. 155-163.

28. Sternberg, R. J. WICS as a model of giftedness. High Ability Studies, 2003, 14 (2), pp. 109-137.

29. Tatum, H., Schwartz, B. M. Honor Codes: Evidence Based Strategies for Improving Academic Integrity. Theory into Practice, 2017, 56 (2), pp. 129-135.

30. Van Eijl, P., Peeters, T., Moesker, H., Dillen, A., Pilot, A., Van Ginkel, S. Honors programs as forerunner for $21 s t$ century skills? Journal of the European Honors Council, 2017, 1 (2), pp.40-53.

31. Weerawarana, S.M., Perera, A.S., Nanayakkara, V. Promoting creativity, innovation and engineering excellence: A case study from Sri Lanka. Proceedings of IEEE International Conference on Teaching, Assessment, and Learning for Engineering, TALE 2012, art. No. 6360374, pp. TC112-T1C17.

32. Wolfensberger, M.V.C. Talent development in European higher education: Honors programs in the Benelux, Nordic and German-speaking Countries, 2015. 335 p.

33. Wolfensberger, M.V.C. Teaching for Excellence. Honors Pedagogies Revealed. Wazmann, Munster. 2012,

34. Wolfensberger, M.V.C., Offringa, G.J. Qualities Honours Students Look for in Faculty and Courses, Revisited. Journal of the National Collegiate Honors Council, 2012, 13 (2), pp. 171-183.

35. Wolfensberger, M.V.C., Pilot, A., Van Eijl, P.J. Laboratories for Educational Innovation: Honors Programs in the Netherlands. Journal of the National Collegiate Honors Council, 2012, 13 (2), pp.149-170.

\author{
Информация об авторе \\ Мария Владимировна Тарасова \\ Россия, Красноярск \\ Доцент, кандидат философских наук, \\ доцент кафедры культурологии, \\ руководитель SibFU Honors College \\ Гуманитарный институт, \\ Сибирский федеральный университет \\ E-mail: mariavtarasova007@gmail.com \\ ORCID: https://orcid.org/0000-0003-4439-8500
}

\author{
Information about the author \\ Maria V. Tarasova \\ (Russia, Krasnoyarsk) \\ Associate Professor, Ph.D., \\ Associate Professor of Culture Studies Department, \\ Dean of SibFU Honors College \\ School for the Humanities, \\ Siberian Federal University \\ E-mail: mariavtarasova007@gmail.com \\ ORCID: https://orcid.org/0000-0003-4439-8500
}

